\title{
PAYEES AS HOLDERS IN DUE COURSE
}

\author{
RALPH W. AIGLER
}

While it is now too late to hope for uniformity of judicial view on the problem of payees as holders in due course ${ }^{1}$ without some revision of the Uniform Negotiable Instruments Law, the question is still an open one in a considerable number of states.

Only infrequently have courts given any attention to the background of the problem; they have been disposed to seize upon certain language in the Act, some of it pointing to one conclusion and some to the opposite, or to be content with the adoption of one of the two views expressed in two or three conspicuous cases decided under the statute. Where the statutory language is clear, courts ought to apply it without regard to the earlier case law of the jurisdiction, but in the case of expressions susceptible of more than one meaning, then it surely is not only proper but necessary to look outside the statutory language. ${ }^{3}$

1 This question is discussed in (1908) 13 L. R. A. (N. S.) 490; L. R. A. 1915 B, 144; (1921) 15 A. L. R. 437; (1922) 21 A. L. R. 1365; (1923) 26 A. L. R.' 769 ; (1924) 32 A. L. R. 289; Hening, The Uniform Negotiablo Instruments Law (1911) 59 U. PA. L. REv. 471; (1916) 64 ibid. 318; (1921) 70 ibid. 52; (1922) 10 CaLIF. L. Rev. 413; (1915) 24 Yale LaW JoURNAL, 429; (1918-19) 28 ibid. 197, 710; (1917) 30 Harv. L. Rev. 515; (1922) 20 MrCH. L. Rev. 908; (1923) 21 ibid. 591; (1924) 22 ibid. 581; (1923) 18 ILL. L. REv. 47; (1924) 9 MINN. L. REv. 101.

2 Certainly the effort toward uniformity has never been more appropriate than in the field of negotiable paper. The Uniform Act in this respect has been productive of much good. No doubt it was too much to expect that any group of human beings would be able to prepare a statute that would be interpreted uniformly in more than four dozen jurisdictions, particularly in view of the fact that the statute did not purport to be al codification of the existing law even of one of those jurisdictions. With the experience of thirty years in dealing with the Uniform Act now availablo it is believed that the Commissioners on Uniform State Laws could well go back to one of their earliest and most important pieces of work and make an attempt to draft suggested amendments to cover difficulties that now appear so clearly.

${ }^{3}$ In Bank of England v. Vagliano Bros. [1891] A. C. 107, 144, Lord Herschell said: "I think the proper course is in the first instance to examine the language of the statute and to ask what is its natural meaning, uninfluenced by any considerations derived from the previous state of the law, and not to start with inquiring how the law previously stood, and then, assuming that it was probably intended to leave it unaltered, to see if the words of the enactment will bear an interpretation in conformity with this view.

"If a statute, intended to embody in a code a particular branch of the law, is to be treated in this fashion, it appears to me its utility will be 
As will be more fully pointed out later on, the legislative language leaves open the problem now under consideration. Accordingly it seems appropriate to begin with a study of the case law as it was prior to the Bills of Exchange Act in England."

According to the early writers on bills of exchange, there ordinarily were four parties to an exchange transactiondrawer, remitter, drawee and payee." Though this practice is no longer so general, it having become increasingly common for the one desirous of transmitting credit to take the bill in his own name which he then indorses over to the one to be put in funds, it is still far from unusual for the transaction to take the earlier form. Many of the cases raising the question as to the poyee being a holder in due course arise out of such situations.

It was fully recognized by the English courts, prior to the Bills of Exchange Act, that a payee in a bill of exchange who took bona fide and for value from a remitter not a party to the instrument was protected as against defenses that might have been available in favor of the drawer against the remitter, had the latter been a party to the document and claimed to recover thereon.

The position of the payee who has received a bill in good faith

almost entirely destroyed, and the very object with which it was enacted will be frustrated. The purpose of such a statute [the Bills of Exchange Act (1882) $45 \& 46$ Vict. c. 61.] surely was that on any point specifically dealt with by it, the law should be ascertained by interpreting the language used, instead of, as before, by roaming over a vast number of authorities in order to discover what the law was, extracting it by a minute critical examination of the prior decisions, dependent upon a knowledge of the exact effect even of an obsolete proceeding such as a demurrer to evidence. I am of course far from asserting that resort may never be had to the previous state of the law for the purpose of aiding in the construction of the provisions of the code. If, for example, a provision be of doubtful import, such resort would be perfectly legitimate. Or, again, if in a code of the law of negotiable instruments words be found which have previously acquired a technical meaning, or been used in a sense other than their ordinary one, in relation to such instruments, the same interpretation might well be put upon them in the code."

Thompson, J., in Nat'l City Bank. v. Nat'l Bank of the Republic, 300 III. 103, 107, 132 N. E. 832, 833 (1921): "The law [N.I.L.] was enacted for the purpose of furnishing in itself a certain guide for the determination of all questions covered thereby relating to commercial paper, and, so far as it speaks without ambiguity as to any such question, reference to case law as it existed prior to the enactment is more likely to be misleading than beneficial."

${ }^{4}$ The provisions of the American legislation in this respect are, generally speaking, obviously taken from the English Act.

5 "Ordinarily there are four persons requisite to be employed in the taking up or remitting any parcel of money by Exchange, (besides the broker which doth procure the parcel) as namely, two at the place where the money is taken up, and two at the place where the money is payable." MLarius, Bills of Exchange (4th ed. 1684) 3. See also Benwes, LEx MERC.1TORIA (2d ed. 1761) 416 (bills of exchange). 
and for value from a remitter was thoroughly examined by the English court in litigation developing out of the failure of the house of Coates \& Company. In Munroe v. Bordier, ${ }^{6}$ a bill had been drawn by the defendant in London, at the request of Coates \& Company, on a drawee in France in favor of the plaintiff. This bill was turned over to Coates \& Company without consideration, it being the understanding that payment by the latter should be made to the defendant on the next foreign post-day. The bill was forwarded to the plaintiff in France who took for value and in good faith. The bill having been dishonored and notice given, action was brought against the defendant, the drawer. The defense relied on was that Coates \& Company had failed before the next foreign post-day and had never paid for the bill. The Court of Common Pleas concluded that the defense was unavailable against the plaintiff. After pointing out that the ordinary course of dealing in the case of foreign bills begins with a sale of the bill by the drawer to some person other than the payee; that it is not, therefore, contemplated "that the consideration for the bill should necessarily move from the payee to the drawer, or that no person but the drawer should have a right to confer a title to the bill upon the payee"; ${ }^{7}$ and in this case the plaintiff had taken the instrument from Coates \& Company for value, bona fide, Wilde, C. J., reached the conclusion that the plaintiff, payee in the bill, should recover. ${ }^{8}$ The case of Puget de Bras $v$. Forbes, ${ }^{0}$ which had been confidently relied upon by the defendant, was distinguished on the ground that in that case the one who procured the bill to be issued by the defendant (drawer) was acting as an agent of the plaintiff (payee).

In Poirier v. Morris, ${ }^{10}$ Coates \& Company had procured on behalf of an American firm another bill on France under circumstances much like those in Munroe v. Bordier. There, too, after dishonor, the payee sued the drawer and the defense of lack of consideration was interposed. The conclusion of the Court of Queens Bench was the same as that reached by the

\footnotetext{
68 C. B. 862 (1849).

${ }^{7}$ Supra note 6 , at 871 . This point of view, that the remitter is in a position "to confer a title to the bill upon the payee," is deeply significant. It will be referred to later on.

8 Arguendo the court said further: "Suppose the bill . . . had been given to them, made payable to the plaintiffs, in order that they, Coates \& Co., might borrow money upon it, or hand it over to the payees, in discharge of a debt, surely the payees, in either case, might sue upon the instrument, without proving the giving of value to the drawer or maker. The want of such value could not be relied upon as an answer to the action, on the ground of the contract between the immediate parties to the instrument being nudum pactum, . . ." Supra note 6, at 873.
}

91 Esp. 117 (C. P. 1792).

102 El. \& Bl. 89 (Q. B. 1853). 
Common Pleas in the earlier case, the remitter again being looked upon as a purchaser of the bill, title to which was conferred by him upon the payee who took for value and in good faith, thereby making any defense, such as lack of consideration, unavailable against him.

In Watson v. Russell, , $^{11}$ the same view is applied on these facts: the plaintiff drew a check in favor of the defendant at the request of $\mathrm{K}$, and handed the instrument to the latter on the understanding that it was to go to the defendant, with a statement that it was to be used only in consideration that a certain ship managed by the defendant should be allowed to go on a certain voyage. The check was delivered by $K$ to the defendant in part payment of a debt without the accompanying message, and the money was collected thereon. In an action by the plaintiff to compel the defendant to refund, the latter was held to be in as good position as if he were suing the plaintiff on the instrument. The court said: ${ }^{12}$

"If A., by means of a false pretence or a promise or condition which he does not fulfil, procures $B$. to give him a note or check or acceptance in favour of C., to whom he pays it, and who receives it bonâ fide for value, $B$. remains liable on his acceptance. His acceptance imports value and liability primâ facie, and he can only relieve himself from his promise to pay $\mathrm{C}$. by showing that $C$. is not holder for value, or that he received the instrument with notice or not bonâ fide. The instrument is one which $\mathrm{C}$. has a right to take, relying on the acceptance or making of the party, and it is no answer to say that'there is no consideration as between him and the acceptor or maker, if the holder took it bonâ fide for value."

The ground of these decisions seems entirely free of doubt. The bill is deemed to be the property of the remitter and it is by and through him that ownership comes to the payee, who, if he is a bona fide holder for value, ${ }^{13}$ will, on familiar principles of the law of negotiable paper, take free of certain defenses. Although the drawer and payee appear on the instrument to be "immediate parties," in truth they are not; the payee, instead of taking as promisee more truly takes as a purchaser. And there were no intimations of any contrary opinion.

113 B. \& S. 34 (Q. B. 1862), aff'd 5 B. \& S. 968 (Ex. Ch. 1865).

123 B. \& S. 34 , at 38.

13 "Holder in due course," which has come into general use under the Bills of Exchange Act and the Negotiable Instruments Law, is the equivalent of the longer expression, used before the legislation, "a bona fide holder for value and without notice." Lewis v. Clay, 67 L. J. Q. B. 224, 228 (1898) per Lord Russell: ". . . the bonâ fide holder for value without notice, or the holder in due course as he is now called." Herdman v. Wheeler [1902] 1. K. B. 361, 370, per Channell, J. 
In a number of cases ${ }^{14}$ language had been used which was susceptible of an indication, one way or another, of the rights of a payee to collect on paper signed in blank or incomplete in some material particular when signed. But these pronouncements were by no means definite or authoritative. As said by Channel, J., in a case decided after the statute, "The cases quoted by the defendant on the argument do not appear, therefore, to help him very much; but, on the other hand, the investigation of the law before the Bills of Exchange Act appears to shew that there is no case which would be a distinct authority in favour of the plaintiff if the law were still as before the Bills of Exchange Act. The law has been stated by various judges ${ }^{10}$ in general terms in such way as to cover the case, ${ }^{17}$ but they do not appear to have had their attention specially drawn to the point" [notes ours].

Occasion for misapprehension as to the true principle involved in some of these decisions was given by the use of language in the opinions suggestive of estoppel. ${ }^{18}$ As will be pointed out. later on, there may be situations in which liability may be fastened upon one or defenses be made unavailable by estoppel, but it certainly is a mistake to attempt to explain the protection of the bona fide purchaser of commercial paper by the doctrines of estoppel. It is, of course, familiar law that as against a holder in due course many defenses are not open, and it is not surprising that frequentiy the result is expressed in language that may be associated normally with an estoppel. It is said,

14 See Garrard v. Lewis, 10 Q. B. D. 30 (1882); France v. Clarke, 26 Ch. D. 257 (1884); Crutchly v. Mann, 5 Taunt. 529 (1814); Harvey v. Cane, 34 L. T. R. (N. S.) 64 (1876) ; Awde v. Dixon, 6 Ex. 869 (1851). In the case first cited, Bowen, J., said, at 35: "I arrive at the conclusion . that a man who gives his acceptance in blank holds out the person to whom it is intrusted as clothed with ostensible authority to fill in the bill as he pleases within the limits of the stamp, and that no alteration (even if it be fraudulent and unauthorized) of the marginal figure vitiates the bill as a bill for the full amount inserted in the body, when the bill reaches the hands of a holder who is unaware that the marginal index has been improperly altered." In France v. Clarke, Lord Selbourne said, at 262: "The person who has signed a negotiable instrument in blank, or with blank spaces, is (on account of the negotiable character of that instrument) estopped by the law merchant from disputing any alteration made in the document, after it has left his hands, by filling up blanks (or otherwise in a way not ex facie fraudulent) as against a bona fide holder for value without notice; but'it has been repeatedly explained that this estoppel is in favor only of such a bona fide holder."

15 Herdman v. Wheeler, supra note 13 , at 369.

16 See supra note 14.

${ }^{27}$ The court was considering the position of a bona fide payee for value who had taken a note improperly filled in by one supposed by the payee - to have been the maker's agent.

18 See, for example, the quotations supra note 14. 
for example, "the defendant is not permitted" to defend on a certain ground, or "he is barred by the instrument coming to the hands of a holder in due course," or even, "The person who has signed . . . in blank ... is (on account of the negotiable character of that instrument) estopped by the law merchant from disputing any alteration." 10 Though the doctrines under which bona fide purchasers of negotiable paper and property generally are protected against defenses and equitable charges in some respects rather closely parallel the principles of estoppel, it certainly is vital to clear thinking that the two concepts be kept distinct. As will be pointed out later on, the unusual protection given innocent takers of commercial paper is due to an application of the principles of bona fide purchase of property, rather than to any extension of the doctrines of estoppel.

\section{BILLS OF EXCHANGE ACT}

This was the state of the English case law when in 1882 the Bills of Exchange Act became law. The Act contains language, so far as it bears on the question under examination, essentially the same as that found in the American legislation recommended by the Commissioners on Uniform State Laws nearly fifteen years later. The English statute ${ }^{20}$ contains the following:

"§ 2-'Holder' means the payee or indorsee of a bill or note who is in possession of it, or the bearer thereof."

"§ 29 (1) -A holder in due course is a holder who has taken a bill . . under the following conditions, namely, . .

"(b) - That he took the bill in good faith and for value, and that at the time the bill was negotiated to him he had no notice of any defect in the title," etc.

"\$ 31 (1) - A bill is negotiated when it is transferred from one person to another in such a manner as to constitute the transferee the holder of the bill."

"(2) - A bill payable to bearer is negotiated by delivery.

"(3) - A bill payable to order is negotiated by the indorsement of the holder completed by delivery."

These are the general provisions that would seem to be in. volved whenever a payee claims to stand as a holder in due course. In addition to these, there are certain other provisions that may be invoked when the question presented involves a particular point. By section 20 it is provided that blanlis must be filled up within a reasonable time and strictly in accordance with the authority given, with the proviso, however, "that if any such instrument after completion is negotiated to a holder in

${ }^{19}$ Lord Selbourne, in France v. Clarke, supra note 14, at 262.

20 (1882) $45 \& 46$ Vict. c. 61. 
due course it shall be valid . . . as if it had been filled up -. . strictly in accordance with the authority given." As to delivery, it is provided in section 21 (2) that "As between immediate parties, and as regards a remote party other than a holder in due course, the delivery [must be by or under the authority of a proper party]. But if the bill be in the hands of a holder in due course a valid delivery of the bill by all parties prior to him so as to make them liable to him is conclusively presumed."

Perhaps it should also be noted here that the Bills of Exchange Act is the result of a deliberate effort to codify the law of England. Only in a few conspicuous instances was it designed to change the law of bills of exchange, promissory notes and checks. ${ }^{21}$ In this country it is equally clear that while the aim of the Negotiable Instruments Law was uniformity among the many jurisdictions in the law of negotiable instruments, this end was to be attained by codification, not of the law of any one jurisdiction, but generally. ${ }^{22}$

The first English case after the statute with any expression of opinion as to the status of a payee as a holder in due course, unfortunately was one in which the problem was not involved, the views advanced being quite unnecessary to a conclusion on the facts. In Lewis $v$. Clay, ${ }^{23}$ the defense by one of two joint makers of a promissory note to an action by the payee was that his signature had been obtained by a representation by the comaker that the instrument signed was of an entirely different character. The court sustained the defense under the doctrine of the well known case of Foster $v$. Mackinnon. ${ }^{24}$ It was pointed out by Lord Russell that even if the defendant had been careless in signing, which it was concluded he was not, the plaintiff could not recover because although he took for value and without notice, being the payee, an immediate party, he could not claim as a holder in due course under the Bills of Exchange Act. ${ }^{25}$

${ }^{21}$ See remarks by Chalmers in the Introduction to Chalmers, Bills of ExchaNGe (8th ed. 1919) xl.

22 The preparation and reception of the legislation were therefore correspondingly more difficult. In framing the proposed statute there was the problem of choice from conflicting views, and in application by the courts after enactment, there was the inevitable tendency to adhere to what had theretofore been decided on in that jurisdiction unless the language of the statute was so explicit as to leave no choice. Although there have been noteworthy exceptions, there has been manifested by the courts of the various states a commendable spirit of co-operation in securing uniformity.

${ }^{23}$ Supra note 13.

24 L. R. 4 C. P. 704 (1869).

25 In Lewis v. Clay, supra note 13, at 227, Lord Russell said: "It will be apparent from a consideration of the facts of the case that the plaintiff was not a 'holder in due course' at all, but that he was, in fact, simply the named payee of two promissory notes. Further, an examination of 
That this case is of little significance on the question under consideration is obvious. In the first place, there was no decision on the point, and in the second, the payee here took directly from one of two co-makers; the payee was an immediate party not only in form, but also in substance.

The dictum in Lewis v. Clay occasioned considerable comment by the court in Herdman $v$. Wheeler:s In that case the defendant signed a blank form of promissory note and placed it in the hands of $\mathrm{A}$, who was to make the loan to the defendant. Purporting to get it on behalf of the defendant, A applied to the plaintiff for a loan in excess of the amount agreed upon between $A$ and the defendant. The plaintiff having indicated his willingness, the note was filled in with the plaintiff's name as payee and an amount twice that agreed upon. The money was advanced by the plaintiff to A (supposedly for the defendant) in good faith, but the defendant never received any of it. In an action on the note the plaintiff sought to prevail over the defense that the completion of the note was contrary to the authority given, by claiming as a holder in due course. It was in this case that Channell, J., after a review of the cases prior to the Bills of Exchange Act, pointed out ${ }^{2 \pi}$ that in respect of the position of a payee against whom is interposed the defense of improper filling of blanks, the law, when the statute was framed, was unsettled, though expressions of the courts pointing either way might be found. He concluded that while under the Act it was perfectly possible that a payee should be a holder in due course, ${ }^{28}$ it could not be said on the facts before the court that "after completion" the note in question had been "negotiated to a holder in due course."

sections . . . will make it quite clear that ' $a$ holder in due coures' is a person to whom, after its completion by and as between the immediate parties, the bill or note has been negotiated. In the present case the plaintiff is named as payee on the face of the promissory note, and therefore is one of the immediate parties. The promissory notes have, in fact, never been negotiated within the meaning of the Act."

${ }^{26}$ Supra note 13.

$2 \pi$ Supra page 612.

28 Reference was made by Channell, $J$., to the language of Lord Fussell in Lewis v. Clay, supra note 13, as follows: "It is quite clear, therefore, that the expression of opinion of the late Lord Chief Justice that a payce was never a holder in due course was a dictum only, and, morcover, as his remarks on the other part of the case appear quite unanswerable, the case could not well have been appealed, and, in fact, was not appealed; so that his dictum could not well be questioned in that case. It appears to us that the late Lord Chief Justice overlooked the definition of holder in $\mathbf{s .} \mathbf{2}$, which is, "Holder means the payee or indorsee of a bill or note who is in possession of it, or the bearer thereof.' Therefore, in $\mathbf{s . 2 9}$, it is necessary to read holder as including payee as well as indorsee, and to read it ' $a$ holder in due course is a payee or indorsee who,' \&c. That being so, the only words in s. 29 which can be said to indicate that a payee cannot be 
To the argument that by section 31 of the Act it is provided "a bill is negotiated when it is transferred from one person to another in such a manner as to constitute the transferee the holder of the bill," the court addressed these questions: "Does this mean only from one person who is holder to another, or may the person transferring be an agent in possession of the bill otherwise than as holder, whose delivery constitutes the receiver a holder? And even if that cannot be the meaning in the 31st section, may it not be possible to say that in the 20th section 'negotiated to a holder in due course' means no more than delivered to a person in such a way that he thereupon becomes a holder in due course?" ${ }^{20}$ The court's answer to these questions is deeply significant in its bearing on the fundamental question of this paper. It was said: ${ }^{30}$

“. . . Even if the payee of a note may be a holder in due course, the question whether he is or not depends upon the actual state of facts as between him and the maker of the note; and the contract between the payee and the maker, though no doubt it has some incidents, such, for instance, as days of grace written into it by the law merchant, yet is governed more by the ordinary law of contracts than by the law merchant, and in particular that the element of negotiability in no way enters into the contract between maker and payee. There is much to support this argument in the Bills of Exchange Act. . . Payees and holders not in due course are, therefore, put on the same footing as regards proof of authority of the person handing them the bill."

This case, then, which has been so frequently cited for the position that payees may not be holders in due course, instead of so deciding, expressly declares the contrary to be the fact; the conclusion is reached merely that within the meaning of the proviso to the 20th section of the Bills of Exchange Act (last sentence of section 14 of the N. I. L.) there had been, after completion, no negotiation to a holder in due course. And this view is arrived at because it was considered that the maker (defendant) and payee (plaintiff) were immediate parties to the contract. Therefore the general principles of contract law should govern. It is to be noted that the intermediate party, A,

a holder in due course are those in sub-s. (b): 'and that at the time the bill was negotiated to him he had no notice of any defect in the title of the person who negotiated it.' But if the word 'payee' had been expressed in the earlier part of the section, it would be clear that this means 'if negotiated to him he had at the time no notice,' \&c. On the whole, therefore, we are not prepared to hold that a payee of a note can never be a holder in due course; but it is, as it seems to us, just as unnecessary for us to decide that question as it was for the late Lord Chief Justice to do so in the case before him."

29 Herdman v. Wheeler, supra note 13, at 373.

30 Ibid. 374. 
at no time even pretended to be the owner of the instrument; the plaintiff dealt with him as an agcut of the other party to the promise.

The force of this decision even thus narrowed is, however, much weakened by the observations of the judges of the Court of Appeal in Lloyd's Bank v. Cooke, ${ }^{31}$ a case in which the defendant after signing notes in blank for the accommodation of $\mathrm{C}$, intrusted them to him on the understanding that they were to be filled in with certain amounts payable to the plaintiff. Contrary to the authority, $C$ filled in a larger sum and the plaintiff took innocently and for value. The court found for the plaintiff on the ground that the defendant was estopped $\$ 2$ by his conduct to raise the question of the filling in being contrary to authority. Collins, M. R., voted for the plaintiff on the ground of estoppel saying that it was quite unnecessary to express any opinion as to the soundness of Heidman v. Wheeler. Cozens-Hardy, L. J., agreed, but said he wanted to keep an open mind as to the earlier case. Fletcher Moulton, L. J., also agreed in the decision, pointing out, however, that the result might very well be reached on the ground that plaintiff, though a payee, was a holder in due course. He said that the law was clearly so before the Bills of Exchange Act and that no change had been wrought thereby. In later cases it seems to be assumed that a payee may be a holder in due course, even under the proviso to the 20 th section. ${ }^{33}$

One more case under the Bills of Exchange Act is strictlyin point. In Gunns Ltd. v. IVart;, a purchaser of fertilizer from a dealer gave a promissory note for the purchase price at the request of the dealer, payable to the manufacturer to whom the dealer was indebted. In an action on the note by the payee against the maker, it was held that the defense of failure of consideration was not available against the plaintiff, a holder in due course. Reliance was placed upon the doctrine of Watson $v$. Russell: ${ }^{35}$ "If A, by means of a false pretence or a promise or condition which he does not fulfil, procures $\mathrm{B}$ to give him a note or cheque or acceptance in favour of $C$ to whom he pays it, and who receives it bona fide for value, $\mathrm{B}$ l'emains liable on his acceptance."

The draftsman of the Bills of Exchange Act points out that

31 [1907] 1 K. B. 794.

32 Doubt was expressed as to whether the doctrine of estoppel was ap. plicable to the facts of Herdman v. Wheeler, supra note 13.

33 Glenie v. Bruce Smith [1908] 1. K. B. 263, per Fletcher MIoulton; Talbot v. Von Boris [1911] 1 K. B. 854; Jones Ltd. v. Waring \& Gillow Ltd. [1925] 2 K. B. 612. The last cited case has, however, been reversed by the House of Lords, it being said that Lord Russell's view in Lewis $r$. Clay, supra note 13, was sound. [1926] A. C. 670.

3451 New Brun. 292 (1924).

35 Loc. cit. supra note 12. 
"any defense available against an immediate party is available against a remote party who is in privity with such immediate party"; and that "Immediate parties' are parties in direct relation with each other. All other parties are remote. Prima facie, the drawer and acceptor, the drawer and the payee, the indorser and his indorsee, are in direct relation." He then uses the following example: ${ }^{36}$

"2. B. makes a note payable to C. Primâ facie B. and C. are immediate parties; but if it appear that $\mathrm{B}$. made the note at the request of $\mathrm{X}$. under the belief that he had done something which he had not done, and that $\mathrm{X}$. on his own account delivered the note to $C$., who gave value and took it without notice, then $B$. and C. are remote parties. Aliter, if X. had been C's. agent."

Until very recently, therefore, there has been little reason to feel doubt as to the status of the English law either before or under the Act. If the payee and maker, either by themselves or through agents, are not really contracting with each other, the payee may well be entitled to the advantages accorded a holder in due course. To the contrary there is the dictum of Lord Russell in Lewis v. Clay and the view expressed by the Divisional Court in Herdman v. Wheeler. In the latter case, however, the decision was limited to the proviso to section 20 (N. I. L., § 14) i.e. if "after completion" the instrument is "negotiated to a holder in due course," it being explicitly stated that according to the language of the act a payee may be a holder in due course. The weight of this decision even thus confined was considerably affected by the language of the Court of Appeal in the later cases above noted.

In the case of Jones, Ltd. v. Waring and Gillow, Ltd. ${ }^{37}$ in the House of Lords, there are expressions of opinion that make it difficult to maintain that under the Bills of Exchange Act a payee may be a holder in due course. The case grew out of the following facts: By false representations $B$ procured from the plaintiffs their check. One of the false representations being that the defendants, well known to the plaintiffs, were engaged with $B$ in a certain fictitious venture, the check was made payable directly to the defendants. In truth $B$ was indebted to the defendants and he turned the check over to them to apply on that debt, their taking being in good faith. Because of a defective execution of the check another in like amount was substituted by the plaintiffs, the new check, as was the old, being payable to the defendants, and they collected the amount therein called for. On the discovery of the facts, action was brought to recover the amount collected by the defendants on the check,

${ }^{36}$ Chalmers, op. cit. supra note 21 , at $111,112$.

${ }^{37}$ Supra note 33. 
the theory of the plaintiffs being in the alternative-money paid by mistake or on a consideration which failed. Darling, L. J., allowed recovery on the first ground. The Court of Appeal (Pollock, MI. R., and Scrutton and Sargant, L. JJ.) reversed the judgment, but in the House of Lords a majority were of the opinion that Lord Darling's conclusion should be upheld. All the Lords who heard the appeal agreed that the defendants were not ones to whom the check had been "negotiated" so as to stand as holders in due course and therefore free of the plaintiffs' claim. Iord Shaw of Dunfermline put it: "ss "The cheque never went into the circle by transfer or indorsation, and it is in these circumstances, in my opinion, inappropriate to use language as to 'a holder in due course' as applicable to the position of a direct payee of a cheque." The view of Lord Russell in Lewis v. Clay on this point was approved and the contrary opinion of Fletcher Moulton, L. J., in Lloyds Bank v. Coole was rejected.

Of course, the decision in the Jones case is only on its facts, and they presented an unusual situation. While the defendants took the check as a payment by $\mathrm{E}$ the plaintiffs never intended $B$ to have any interest therein; the plaintiff intended to deal with the defendants, and the check on which the money was paid was given by the plaintiffs directly to the defendants. However this may be, the generality of the language as to the situation of a payee under the Bills of Exchange Act leaves it very difficult for any other and therefore inferior English court to reach what is believed to be the sound conclusion.

\section{EARLY AMIERICAN CASES}

In the United States, until about ten years after the N. I. L., the development of the law on this subject generally paralleled its course in England. Prior to the Uniform Negotiable Instruments Law, the cases and writers were pretty well agreed that a position as payee did not necessarily mean that one could not stand as a holder in due course, to use the expression which came into common use after the legislation. ${ }^{3}$ In the cases cited,

38 [1926] A. C. 670 , at 687 .

39 Cagle v. Lane, 49 Ark 465 (1887) ; So. Boston Iron Co. v. Brown, 62 Mie. 139 (1873) ; Glasscock v. Rand, 14 Mro. 550 (1851); Jordan v. Jordan, 78 Tenn. 124 (1882); Lookout Bank v. Aull, 93 Tenn. 645, 27 S. W. 1014 (1894) ; Armstrong v. Bank, 133 U. S. 433, 10 Sup. Ct. 450 (1890) ; Passumpsic Bank v. Goss, 31 Vt. 315 (1858); Dixon v. Dixon, 31 Vt. 450 (1859) ; F. \& MI. Bank v. Humphrey, 36 Vt. 554 (1864) ; Frank \& Adler v. Lilienfeld, 33 Gratt. 377 (Va. 1880); 1 DaNiEL, Negorlable Instnunesis (6th ed. 1913) \$ 175; 1 Parsons, Notes AND BILLS (1S73) 181. But see Chariton Plow Co. v. Davidson, 16 Neb. 374, 20 N. W. 256 (1884).

In 1 DANIEr, loc. cit. supra, it is said, "Who are the immediate parties to a bill or note, however, does not always appear on its face. The name 
the conclusion was reached over a variety of defenses as, for example, lack or failure of consideration, negotiation contrary to understanding or without procuring signatures of additional parties as agreed, etc. In some of them, no doubt, the decisions were, or might have been, rested wholly or in part on other grounds. The recognition of the doctrine of the English decisions along this line is, however, clear, such cases as Munroe v. Bordier, Poirer v. Morris and Watson v. Russell being frequently relied upon.

Before considering the statutory language and the cases that have been decided in this country since the N. I. L., it may be helpful to give some attention to what fairly appear to have been the considerations underlying the then generally accepted doctrines, when the Commissioners on Uniform State Laws undertook the task of framing a comprehensive code.

Bills of exchange, the common use of which has been due largely to the need for some convenient and safe means of transferring credits without the trouble and danger of handling money or other valuable property, have frequently been likened to money, and much of the law of such documents is due to the desire to make them circulable much like money. Although promissory notes have not quite the same reason for their origin and development, the disposition has been strong, particularly since the Statute of Anne, ${ }^{40}$ to deal with them as upon the same footing at least so far as their circulation is concerned.

Now the law of bills and notes is an interesting combination of well known principles of contract and property law, modified sometimes to suit the peculiar conditions involved in problems of commercial paper. The obligations of parties to such paper are essentially promissory, and holders thereof must necessarily proceed for realization on the paper as upon promises. As a matter of contract law, it was too clear for argument that the rights of any successor to the promisee were no greater than those of the promisee himself. Indeed it was not easy for the assignee of the promises to claim even as much as could the promisee himself. And the claims of the promisee were clearly subject to any infirmities in the promissory obligation. In other words, that any defense to an action on the promise should not be open for the promisor to make was not even a matter for argument. Analogies for the familiar doctrine that a bona fide pur-

of the payee is often left blank, or there is an indorsement in blank upon the instrument, and in such cases when the blank is filled up with tho holder's name he would appear to be the original payee or indorsee. In such cases the holder may show that his ostensible is not his real relation to the paper; and the want or failure of consideration cannot be pleaded against him if he show that it has passed through intermediate hands, and that he is not the immediate promisee of the party making the defense."

40 (1704) 3 \& 4 Anne, c. $9, \S 1$. 
chaser of commercial paper may not be subject to defenses to the promise sued upon must be sought outside the field of contract law. When the courts began to recognize that a bona fide purchase might strip the obligation of defenses, there vere well known situations in the realm of property law in which a bona fide purchaser did stand better than his transferor;, and it would not be surprising if these instances served as guiding analogies. The bill or note, particularly the former, was a substitute for money which was property, the bona fide purchaser of which was protected against certain infirmities in the title. $^{42}$ To this extent, the bill or note was looked upon, not as the evidence merely of certain promissory undertalings, but as a piece of property.

If the question were between the parties to the promise, it was natural that the familiar rules of contract law should apply, and any infirmity could be relied upon in defense. On the other hand, if the enforcement of the promise was sought, not by the other party thereto, but by a purchaser, the principles of property law ${ }^{43}$ extending protection to the innocent purchaser were applicable. Thus we have in so many cases and texts the discussions of "immediate" and "remote" parties.

In form always and in substance usually, the payee is the party to whom the maker's or drawer's promises are made. An instrument with a blank for the name of the payee may be issued to $A$ and after passing through any number of other hands as the property of each successive party, may be filled in by $x$ with his own name as payee. While $X$ would appear as the promisee, the fact is that he has taken as a purchaser and is clearly a

41 That a bona fide purchaser of legal interests should talie free of equitable charges was familiar as was also the common principle of commercial law protecting the innocent purchaser in market overt.

42 In 2 AMTES, CASES on BILLS \& NOTES (1881) 866 , it is said: "It is a familiar doctrine of equity that one who purchases a legal title for value and without notice, takes the title discharged of all equities to which it was subject in the hands of his vendor, e. g., a trust, or equitable right to a reconveyance on the ground of fraud; for an equity, being in its nature a claim in personam and not in $r \mathrm{em}$, can be enforced only against a party to the transaction in which the equity arises, or some one in privity with that party. (Langdell, Summary of Equity Pleading, \$ 141.) The transfer of bills and notes, by virtue of their negotiability, is governed by the same principle."

The following language in the early case of Husscy v. Jacob, $1 \mathrm{Ld}$. Raym. 87 , at 88 (K. B. 1696) is also significant: "So in this prineipal case, if the bill of exchange had been afterwards assigned for a valuable consideration, the honesty of this assignment had purged the original cantier and rendered it good enough. As where a fraudulent conveyance is assigned upon a valuable consideration, the fraud is purged."

${ }^{43}$ Of course, the reason for looking to the field of property law for the guiding principle is to be found in the appeal of commercial policy, the circulability of commercial paper. 
remote party. So in the common case of a bill of exchange procured by a remitter in the name of his creditor, the payee, though ostensibly a party to the promise, really takes as a purchaser from the remitter, and is, therefore, a remote party. It is quite evident from the cases that have been herein considered that this line of distinction was observed, at least prior to the codifications of the law of negotiable paper.

There are good reasons for extending special protection to purchasers of commercial paper. The part played by such paper in the shifting of credits, payments, etc., in the commercial life of the country demands that the innocent taker for value shall normally be protected, as he would be if money were taken instead of a bill or note. But as between the promisor and promisee, who are dealing directly and as such, the instrument has not yet become any part of the credit structure and there is no commercial need for the paper to be likened to money. Speaking of the contention of counsel in Herdman $v$. Wheeler it was said: ${ }^{44}$

“. . . He contends that the rule that one holder of a negotiable instrument can give a better title to it than he himself possessed is based upon the view that negotiable instruments are currency, and that it is on their passing from hand to hand, and not on their coming into being, that negotiable instruments acquire their special validity in the hands of a holder in due course. Even if the payee of a note may be a holder in due course, the question whether he is or not depends upon the actual state of facts as between him and the maker of the note; and the contract between the payee and the maker though no doubt it has some incidents, such, for instance, as days of grace written into it by the law merchant, yet it is governed more by the ordinary law of contracts than by the law merchant, and in particular that the element of negotiability in no way enters into the contract between maker and payee."

And Channel, J., added:

"There is much to support this argument in the Bills of Exchange Act."

That a payee may acquire his rights upon commercial paper by purchase as well as by promise seems too clear for argument. The "remitter" transactions are conspicuous. The payee's rights in these situations are as truly acquired by purchase as if the instrument were made payable to the order of the remitter and indorsed by him. The remitter is the owner of the paper before it comes to the hands of the payee. ${ }^{45}$ The cases before the

\footnotetext{
44 Supra note 12 , at $373-374$.

45 See cases involving remitters, supra. Also, see Sutherland State Bank v. Dial, 103 Neb. 136, 170 N. W. 666 (1919); (1919) 28 YALE LAW JOURNAL,
} 
codifications in England and the United States treating the payee as a holder in due course were quite uniformly instances of the payee taking as by purchase, rather than by promise. ${ }^{86}$ It is not easy to point to definite authority that a payee taking directly as a promisee was not looked upon as a potential holder in due course, but the language used and the principles relied upon were quite inconsistent with such result.

With this background, one may approach the question of the meaning of the legislative language, remembering, of course, that the statutes were supposed to state existing law. So far as the English cases are concerned, as pointed out above, against a payee being a holder in due course under the Bills of Exchange Act until the recent case of Jones $v$. Waring, there were only the dictum of Lord Russell in Lewis v. Clay and the decision in Herdman $v$. Wheeler in which the payee took not as a purchaser but as a promisee. ${ }^{27}$ Before considering the American decisions under the Negotiable Instruments Law it seems appropriate to analyze the statutory provisions with a view to determining, if possible, whether the legislative language leaves any room for interpretation.

EFFECT OF THE N. I. L.

The statute, in section 52, declares that a "holder in due course" is a "holder" who has taken the instrument under certain conditions, the only one important to mention being: "4. That at the time it was negotiated to him he had no notice of any infirmity in the instrument or defect in the title of the person negotiating it." That a paree may be a "holder" is left wholly without doubt by section 191, which provides that "holder"

695. Brummel \& Co. v. Enders, 18 Gratt. 873 (Va. 1868) is an interesting instance of one in form a payee being treated as a purchaser, a defense of usury being unavailable.

46 Looking upon the remitter as the owner, as he is in truth, contemplating a sale to the named payee, it would not be an unressonable view that such payee who takes in good faith and for value should be accorded the protection normally associated with holders in due course even though the instrument omits words of negotiability and is therefore really a nonnegotiable bill or note. Such was the result in some of the cases. See Armstrong v. Bank, supra note 39; F. \& MI. Bank v. Humphrey, supro note 39; Horn v. Fuller, 6 N. H. 511 (1834).

${ }^{47}$ If the suggested view that the payee must talie as a puchoscr from one who is or appears to be a prior owner in order to ranl as a holder in due course is accepted, as it was before the Bills of Exchange Act, then the proviso to section 20, dealing with instruments which after completion are "negotiated" to holders in due course, upon which Hcrdman $v$. Wheeler turned, was properly construed. "Negotiated," as used in the proviso, was given an interpretation which lead to a decision under the statute in accord with what it would have been before the Act. 
means "the payee or indorsee of a bill or note, who is in possession of it, or the bearer thereof." So far, then, the language manifestly would include a payee among those who may be holders in due course.

But paragraph 4 of section 52 , above quoted, speaks of a negotiation - "That at the time it was negotiated to him," etc. In the discussions of this subject it has generally been taken for granted that paragraph 4 lays down a positive requirement that the instrument must have been "negotiated," and the divergence of opinion has come thereafter in determining whether an instrument in the hands of the payee can be said to have been "negotiated." It should be observed, however, that while the first three paragraphs lay down requirements essentially affirmative in character, the fourth paragraph contains a negative requirement-there must have been, on the part of the claimed holder in due course, no notice of infirmity or defect in the title. The sting of the paragraph would seem to be in the lack of notice rather than in the negotiation. If "negotiation" is to be limited in its meaning to transfers between successive holder's, might not the paragraph under examination be read as follows: "That at the time it was negotiated to him (if the claimed holder" in due course came by the instrument by negotiation) he had no notice," etc?

However, if this be not considered a sound view, the next inquiry is whether under the terms of the statute there may be a "negotiation" between a maker or drawer and a payee. It is of course obvious that the question arises normally when the negotiations for floating or circulating the instrument are conducted through an intermediary. By section 30 "negotiation" is dealt with. It is there provided that "an instrument is negotiated when it is transferred from one person to another in such manner as to constitute the transferee the holder thereof." Our inquiry under this, then, becomes simply: may one reasonably say that delivery, for example through an intermediary, to the payee is a transfer constituting the transferee the holder? As pointed out above, it is expressly declared by the Act that a payee may be a holder. How about delivery amounting to a transfer? Ordinarily we think of the initial delivery of the instrument as accomplishing its issuance; but "transfer" is one of the words used in the statute in defining "delivery." 48 The language is: " 'Delivery' means transfer of possession, actual or constructive, from one person to another." To the payee certainly there is a transfer of possession, actual or constructive. All this would fairly indicate that issuance of the instrument by delivery to the payee might well be deemed a "negotiation"; and no doubt the average business man would not be shocked to be

\footnotetext{
48 Section 191.
} 
told that in making "delivery" of his promissory note to the payee bank which advances the money thereon he has "negotiated" his note.

But there is a second sentence in the makeup of section 30 . It states: "If payrable to bearer it is negotiated by delivery; if payable to order it is negotiated by the indorsement of the holder completed by delivery." Here clearly the negotiation of instruments already issued is referred to; and the balance of the sections in the third article, in which section 30 is the first section, equally clearly deal with issued instruments. It is interesting to observe, though, that in section 50, the concluding section of the third article, issuance, or more specifically reissuance, and negotiation are used apparently interchangeably. The first sentence of section 30 seems to be a broad, general declaration; the second sentence does not appear by its language to limit the first, but rather to attempt to provide for two special types of situations included within the general scope of the language in the first sentence.

That under the N.I.L. the door is not closed to considering a payee in an appropriate case as a holder in due course seems without doubt, particularly when the statute is read, as it must be, in light of the fact that it purports, generally spealing, to be only a codification of existing law.

The first case ${ }^{4}$ under the N.I.L. involving the question was one in which the payee took for value and in good faith from an ostensible remitter. Over defenses based on the improper filling in of blanks and the diversion of the instrument to nonintended purposes, the court held the payee a holder in due course. It was pointed out that at common law sy a payee might occupy such favored position and by the codification in England and this country the law in this respect had not been changed. The court said: ${ }^{51}$

“. . . . In our opinion, a check received by the payee named in it, in payment of a debt due from the remitter of the check, is received by a holder in due course within $\$ 69$ [52] of the negotiable instruments act, . . . and that is so even if we should follow the decision made in Herdman $v$. Wheeler, [1902] 1 K.B. 361, and hold that a payee never can be a holder in due course to whom the bill has been 'negotiated,' within the last clause of $\S 31$ [14] of our act, . . . which is taken from $\S 20$ of the English bills of exchange act of 1882."

49 Boston Steel \& Iron Co. v. Steuer, 183 Miass. 140, 66 N. I. 646 (1903).

50 The cases relied upon were Watson v. Russell, supra note 11; Poirer $v$. Miorris, supra note 10; Munroe v. Bordier, supra note 6; Nelson v. Cowing \& Seymour, 6 Hill, 336 (N. Y. Sup. Ct. 1844); Armstrong v. Banls, supra note 39.

51 Supra note 49 , at 144,66 N. E. at 648. 
Two years later, in Thorpe $v$. White, ${ }^{52}$ the same court held a payee not subject to the defense of material alteration made by the maker after the note had been signed by the defendant as an accommodation indorser and before delivery to the plaintiff payee. The payee was deemed to have become a "holder" by negotiation under section 52 (N.I.L.) and a holder in due course without notice of the alteration under section 124.53 On such facts it is difficult to see how the payee can be considered as taking by purchase.

The next case in point of time is one which seems to be largely responsible for the line of American authority that a payee cannot be a holder in due course. ${ }^{54}$ The payee for value and in good faith had taken the note involved in that case from one of three joint makers after it had been filled in, by the one with whom the payee dealt, with an amount contrary to the agreement upon which the other makers had signed their names. The question was whether within the proviso to section 14 (N.I.L.) the note after completion had been "negotiated to a holder in due course," and it was decided that under the definitions and provisions found in sections 191, 52, 59 and 57 the payee here should not be deemed in that favored class. The court said: 55

"The latter term (holder in due course) seems unquestionably to be used to indicate a person to whom after completion and delivery the instrument has been negotiated. In the ordinary case the payee of the instrument is the person with whom the contract is made, and his rights are not in general dependent on any peculiarities in the law of negotiable instruments."

It was carefully pointed out, however, by the court that they did not want to be understood as taking a position that in no case could a payee be a holder in due course, and the remitter transaction was referred to as one in which both before and since the statute a payee might be a holder in due course. ${ }^{60}$ The de-

52188 Mass. 333, 74 N. E. 592 (1905).

53 "But when an instrument has been materially altered and is in tho hands of a holder in due course, not a party to the alteration, he may enforce payment thereof according to its original tenor."

${ }^{54}$ Vander Ploeg v. Van Zuuk, 135 Iowa, 350, 112 N. W. 807 (1907). In Black Hawk Bank v. Monarch Co., 207 N. W. 121 (Ia. 1926) the court said there was no need, on the facts, to discuss the much mooted question whether a payee may be a holder in due course.

5s Vander Ploeg v. Van Zuuk, supra note 54, at 353, 354, 112 Pac. at 808. .

56 The court cited Watson v. Russell, supra note 11, and Armstrong v. Bank, supra note 39. The case of Boston Steel and Iron Co. v. Steuer, supra note 49 , was disapproved because there had been no delivery of the check to the third party with the intent to make the instrument operative. It was not to be effective until delivered to the payee. The Iowa court, however, either overlooks or deems unimportant the fact that the payee in the Steuer case took the check under circumstances warranting the belief that the third party was in the position of a remitter. 
cision of the English court in Herdman v. Whecler, on facts essentially the same, was approved.

For the minority though not uncommon view in the American cases, that a payee need not contend for protection as a holder in due course, this Iowa decision is largely responsible; at least it appears to have been the authority commonly relied upon. In virtually all of the cases cited for the minority view, however, the payees, as in the Vonder Plocg case, in no true sense took as purchasers but as promisees in a transaction with the promisors, or one of them, directly or through an agent.jr Frequently in these cases it is said that one cannot become a holder in due course unless by negotiation from a "holder," and if the term is used as defined in the N.I.L., that would mean that not even in the remitter cases could the payee be a holder in due course. The expressions, however, are merely dicta. There is very little, ${ }^{5 s}$ if any, real authority for the proposition that a payee who purchases the instrument from one who does not appear

57 Consolidated Wagon \& Machine Co. v. Housman, 38 Idaho, 343, 221 Pac. 143 (1923) (not even citing Redfeld v. Wells, 31 Idaho, 415, 173 Pac. 640 (1918) in which the Steuer case in Mrassachusetts was expressly approved); Builders' Lime \& Cement Co. v. Weimer, 170 Iowa, 444, $151 \mathrm{~N}$. W. 100 (1915) ; Devoy \& Kuhn v. Huttig, 174 Iowa, 357, 156 N. W. 412 (1916); Southern Nat'l Realty Corp. v. People's Bank, $178 \mathrm{Ky} .80,198 \mathrm{~S}$. W. 548 (1917); First Nat'l Bank v. Allen, 88 Okla. 162, 212 Pac. 597 (1929); Strother v. Wilkinson, 90 Okla. 247, 216 Pac. 436 (1923); Rice v. Jones, 102 Okla. 30, 225 Pac. 958 (1924) ; Britton Milling Co. v. Williams, 44 S. D. 525, 184 N. W. 268 (1921) ; Tripp State Bank v. Jerke, 45 S. D. 448, 188 N. W. 314 (1922); Walker v. Traylor Co., 12 Fed. (2d) 382 (C. C. A. Sth, 1926).

In Rice v. Jones, supra, the Oklahoma court, after pointing out the conflict of authority and that in the earlier case of First Nat'l Bank v. Allen, supra, the view that a payee cannot be a holder in due course had been adopted, supported its conclusion by a novel argument. It was said at 32, 33, 225 Pac. at 960: "The common acceptance of the meaning of the word 'course' contemplates a sequence of events or a succession of acts connectedly followed, and a holding that one act or transaction between maker and payee may be in a 'course' is a strained construction of the wrord."

58 St. Charles Savings Bank v. Edwards, 243 Mo. 553, 147 S. W. 978 (1912) may be a case of a payee taking as purchaser from a remitter, but the case is decided on the ground that the payee in any event was not a holder in due course, for there was no innocent taking; it was pointed out that the conclusion would have been the same if the notes had been payable to the intermediate party and by him indorsed over to the one who claimed to be an innocent purchaser. In Weller v. Mieadows, $272 \mathrm{~S}$. W. 85 (Mo. App. 1925) in which a party was claiming to be a holder in due course, the court rejected the contention saying, at 90: "In the first place, he is named as payee in the notes, and, while this is not conclusive, it is an item in defendant's favor. A holder in due course is one who has talien the instrument under the following conditions . . . and this clearly contemplates that to be a holder in due course the holder must have ac- 
to be a promisor in the instrument itself (in other words, the two-transaction situation of which the remitter case is the common type) cannot stand as a holder in due course.

If the foregoing analysis of this problem is sound, one would expect that the cases in which payees were held to be holders in due course were instances of purchase in what were, or appeared to be, two-transaction situations, as in Boston Steel and Iron Co. v. Steuer. ${ }^{5 \theta}$ Some of the decisions have been of that character ${ }^{60}$ and occasionally the need for the two-way deal has been emphasized. For example, in Howard National Banliv. Wilson, ${ }^{61}$ the court says:

“. . . the cardinal purpose of the principles developed in the law merchant has been the protection of a bona fide holder for value who has acquired a negotiable instrument in the due course of trade or business. Commercial paper serves as common currency. Its unhampered use is indispensable to the business of the modern world. Any medium of exchange cannot have free currency without confidence; an experience has taught that it is dangerous to cast doubt even upon a payee's right to recover when he has taken commercial paper complete and regular on its face, honestly and for value. . . The only provision of the Act (N.I.L.) even suggesting that it was intended to exclude a payee in every case from the status of a holder in due course is found in Section 52, subd. 4; but such is not its necessary implication. The question turns on the meaning of 'negotiated' as employed in this section. Its common legal

quired the note by negotiations and transfer from the payee, or prior in.dorsee, and not by issue or delivery from the maker."

Washington cases may be cited on each side. Bowles Co. v. Clark, 59 Wash. 336, 109 Pac. 812 (1910); State Bank v. Pacific Grain Co., 125 Wash. 149, 215 Pac. 350 (1923); Ladd \& Tilton Bank v. Small, 126 Wash. 8, 216 Pac. 82 (1923). In the case last cited, the court (Department 1) was of the opinion that a payee could not be a holder in due course, relying largely on language of Fullerton, J.; in the case in Department 2, that judge was saying, at 152, 215 Pac. at 351: "It is not the rule that a payco named in a draft or check can, under no circumstances, be a holder in due course. We need not point out the many instances where he is such," etc.

In Woods v. Finley, 153 N. C. 497,69 S. W. 502 (1910), cited occasionally for the view that one may become a holder in due course only by "negotiation," meaning thereby, if the instrument is an "order" one, by indorsement, the language to that effect was used in respect of a claim by a possessor of an order note unindorsed by the payee.

59 Supra note 49.

60 Drumm Construction Co. v. Forbes, 305 Ill. 303, 137 N. E. 225 (1922); Bank of Commerce v. Randell, 107 Neb. 332, 186 N. W. 70 (1921) [of. Hartington Nat'l Bank v. Breslin, 88 Neb. 47, 128 N. W. 659 (1910)]; Brown v. Rowan, 91 Misc. 220, 154 N. Y. Supp. 1098 (City Ct. 1915) ; Bergstrom v. Ritz-Carlton Co., 171 App. Div. 776, 157 N. Y. Supp. 959 (1st Dept. 1916); Johnston v. Knipe, 260 Pa. 504, 105 Atl. 705 (1918); Howard Nat'l Bank v. Wilson, 96 Vt. 438, 120 Atl. 889 (1923).

61 Supra note 60, at 447, 120 Atl. at 892. 
significance is 'concluded by bargain or agreement.' So, a promissory note, complete as to form and parable to a named person may be negotiated to that person by being sold to him or taken by him for value."

But in a considerable number of cases the same result has been reached though the payee dealt directly with the promisors. In reaching this conclusion it is said that paper may be "negotiated" to the payee, that word being given "its common legal significance of concluded by bargain or agreement"; and, therefore, that "a promissory note complete as to form and payable to a named person may be negotiated to that person by being sold to him or taken by him for value." ${ }^{63}$ This is an even broader view than that entertained by the Pennsylvania court in JoInston $v$. Knipe, in which the question was whether a a payee who took directly from the maker was to be considered as a holder in due course as to one who had indorsed at the request of the maker on the understanding that plaintiff's name would not be written in as payee. The court considered the case the same as if the note had been given by the defendant indorser payable to the maker who, in turn, had sold it to the plaintiff. " "Even if in certain cases," "the court said, (quoting the lower court's opinion) " 'a payee is not a holder, in due course,

62 Ex parte Goldberg \& Lewis, 191 Ala. 856 , 67 So. 899 (1914); Baggish v. Offengand, 97 Conn. 312, 116 Atl. 614 (1922); Thompson v. Bank, 80 Ga. App. 443, 118 S. E. 470 (1923) ; First Nat'l Bank of Herington v. Banl, 100 Kan. 194, 200, 164 Pac. 137, 139 (1917) (dictum); Thorpe v. White, supia note 52; Liberty Trust Co. v. Tilton, 217 IIass. 462,105 N. E. 605 (1914) ; Colonial Fur Ranching Co. v. First Nat'l Bank, 227 31ass. 12, 111 N. E. 731 (1917) ; State Bank v. Missia, 144 Minn. 410, 175 N. W. 614 (1920) (semble); Mierchants Nat'l Bank v. Smith, 59 Miont. 230, 196 Pac. 523 (1921) ; American Nat'l Bank v. Kerley, 109 Or. 155, 220 Pac. 116 (1923) (repudiating indication to contrary in Banl: of Gresham v. Walch, 76 Or. 272, 117 Pac. 534 (1915); Snyder r. MicEwen, 148 Tenn. 429, 250 S. W. 434 (1923) ; Security Trust Co. v. Foster, 249 S. W. 227 (Tex. Cit. App. 1923).

63 Liberty Trust Co. v. Tilton, supra note 62 , at 464,105 N. E. at 606. This case involved the application of section 16 of the N.I.L. (Eection 20 in Massachusetts): ". . . As between immediate parties, and as regards a remote party other than a holder in due course, the delivery, in order to be effectual, must be made either by or under the authority of the party making, drawing, accepting or indorsing, as the case may be," ete. The payee was not necessarily an "immediate" party. The court said that these words "immediate parties" "must be confined to parties who are 'immediate' to the conditions or limitations placed upon the delivery in the sense of knowing or being chargeable with notice of them." Liberty Trust Co. v. Tilton, loc. cit. supra. That this is the true meaning of the rords one may well doubt; the expression "immediate parties" had a well lnown meaning before the N.I.L. was thought of, and it was not the meaning the court here entertained.

64 Supra note 60. 
we are of opinion that under the facts before us . . . [the plaintiff] is such holder." "65

To say that a payee in the usual case, though he takes for value, purchases the instrument, is, it is submitted, to misstate the real nature of the transaction. The value he gives is the consideration for the promise or promises of those whose paper it is, not the purchase price. It is then that the instrument begins its commercial life, and as yet there is nothing to which to apply the doctrines of bona fide purchase. Thereafter it may be the subject matter of a purchase even by the named payee if he deals with one actually or apparently the owner thereof.90 The need for protection of the innocent taker arises, as pointed out above, not in the inception of the paper but when it is sought to use it as part of the exchangeable credit of the business world.

Of course if the codifications make it clear that all payees whether taking as promisees or as purchasers are entitled to rank as holders in due course if the stipulated requisites such as taking for value, in good faith, before maturity, etc., are present, there is no use pointing out that under the common law such was not the case. Nor would there be any occasion for recalling that it is the purchaser who presents the case for needed special protection. It has been pointed out time after time that the legislation both in England and this country was intended merely to state existing law. The fact that a number of courts of distinction have concluded that under the N.I.L. no payee can be a holder in due course seems strong proof that the language of the statute is not so clear as to leave no occasion for interpretation in the light of the previous law on the subject.

Since by the statute payees are holders, and holders are presumptively holders in due course, is it to be said that every payee is prima facie a holder in due course? It is conceivable that such should be the result. But reading the statute in the light of the common law and remembering that in a very large percentage of transactions the instrument in its inception comes to the payee as a promisee and not as a purchaser, would it not more reasonably be concluded that a payee is not entitled to the

65 Ibid. 509, 105 Atl. at 706.

${ }_{66}$ Empire Trust Co. v. Manhattan Co., 97 Misc. 694, 162 N. Y. Supp. 629 (Sup. Ct. 1916), aff'd 180 App. Div. 891, 166 N. Y. Supp. 1093 (1st. Dept. 1917 ) is interesting and instructive. The payee in a certified check gavo value therefor in a transaction supposedly with an agent of the drawer. In truth, the pretending agent was a thief. The payee therefore did not purchase the paper from one even an apparent owner; it supposed it was taking the instrument from the drawer, that the transaction in which it acquired the paper was its inception. The court held the payee, though an innocent taker for value, not a holder in due course, because the check had not begun its commercial life before the payee took it. 
presumption unless it first appears that he took by purchase? ${ }^{\text {co }}$ After all, whether a payee is a holder in due course is a question not susceptible of a categorical answer. In each instance the conclusion should depend upon the type of situation presented. No doubt, prima facie, a payee is not a holder in due course because presumptively he took the instrument as promisee rather than as a purchaser. But it always should be open to proof that he really acquired the paper in the latter capacity, in which event his status may be that of a due course holder.

67 In Talbot v. Von Boris, supra note 33, an action by the payee, one of the makers defended on the ground that her co-maker procured her signature by duress, and it was argued that the duress being shown it then became incumbent upon the plaintiff to assume the burden of proof that he had taken for value, in good faith, and without notice. Section 30, sub-s. 2 of the Bills of Exchange Act (section 59, N.I.L.) was relied upon. The court thought that the plaintiff in any event had probably satisfied that burden. As to the interpretation of the statutory provision, the view of the judges is well indicated by the following language by Farwell, L. J., at 865: "The only other point is as to the construction of s. 30, sub-s. 2 , of the Bills of Exchange Act, 1882. I agree with Vaughan Williams L. J. that up to a certain point in that sub-section the language is such as might include the payee originally advancing money to the maker of a promissory note as in the present case. The hypothesis upon which the sub-seetion proceeds is that the original issue of the negotiable instrument is affected with fraud or duress, or illegality, i. e., that the person who originally took the instrument is in some way affected by his own misconduct, so as to vitiate the instrument in his hands. In that case the effect of the sub-section clearly is that a subsequent holder cannot enforce the instrument unless he can shew that, subsequently to the alleged fraud or illegality by which the issue of the instrument is affected, he gave value in good faith for the instrument; but the language of the sub-section does not seem to me to be consistent with its provisions being applicable as between the parties to the original transaction by which money was borrowed and lent upon the notes."

In Colonial Fur Ranching Co. v. Bank, supra note 62 , there is some very general language indicating an opinion that any payee is prima facie a holder in due course. In MIcLaughlin v. Paine Furniture Co., 245 MIass. 377,139 N. E. 542 (1923) a payee in a remitter transaction was held entitled to the presumption, according to N.I.L., $\$ 59$. And in Howard Nat'l Bank v. Wilson, supra note 60 , at 449,120 Atl. at 893 , where the same result was reached, the language of the court ("The note was procured by Elliott for his personal accommodation, and was made payable to the plaintiff with a view to securing the loan from it, a stranger to the transaction") indicates a viewing of the payee as a purchaser. 